\title{
Restorative Justice in Indonesia: Traditional Value
}

\author{
Eva Achjani Zulfa ${ }^{1}$
}

\begin{abstract}
"Restorative Justice" is a model approach which emerged in the 1960s in an effort to solve criminal cases. Unlike the approach used in conventional criminal justice system, this approach focuses on the direct participation of perpetrators, victims and society in the settlement process. This theory of the approach is still debated, but the view is in fact growing and it exercises a lot of influence on legal policies and practices in several countries. The UN through its basic principles considers the approach of restorative justice as the approach which could be used in the rational criminal justice system. Restorative justice is a concept of thinking that supports the development of the criminal justice system with emphasis on the required involvement of the community. It is also involving the casualties who with the current criminal justice system are excluded. In several countries, restorative justice has been translated into a variety of formulations to accommodate a variety of values, philosophical basis, terms, strategies, mechanisms, and programs. Good consultation with the perpetrators and the victims themselves may provide the public with a different mindset in preventing emerging problems. This process can involve the police, prosecutorial institution or the traditional institutions. Therefore, without excluding the work in the formal legal system, the institutional mechanism for resolution through consultation was working in the community. In the various principles and models of the restorative justice approach, the process of dialogue between the perpetrator and the victim is a fundamental and the also the most important part of the application of the restorative justice. The direct dialogue between the perpetrator and the victim gave the victim the opportunity to express what he/she felt, hope for human rights and the desire to reach a criminal settlement.
\end{abstract}

\section{Introduction : The Background of Restorative Justice}

In many countries, there is dissatisfaction and frustration in the application of formal criminal law. The conventional criminal justice system did not offer justice for people, no protection for the victim and it gave no benefit to the society. Therefore, it has triggered some thoughts to look for other alternative handling of criminal acts in those countries. The long standing and current application of criminal court proceedings shows that the system is no longer adequate in order to provide protection of human rights nor is it transparent to the public.

Every five years United Nations organizes the well known "Congress on Crime Prevention and the Treatment of Offenders". The congress discusses the

1 Lecturer of Criminal Law at Faculty of Law, University of Indonesia. The author welcomes all comments at eva.zulfa@ymail.com 
development of crime, the handling and management of perpetrators of crimes and other related topics. The congress also welcomes countries to share their experiences from a number of developed programs as well as emerging practice issues. On this occasion, a number of countries also use the opportunity to establish crime prevention/reduction cooperation frameworks, particularly for country wide criminal activities. ${ }^{2}$

In 1990 and 1995 Non-Governmental Organizations from several countries sponsored particular Congress meeting-sessions to discuss restorative justice. Since then, a variety of interests and programmes as well as policies have been developed by using this approach. In the 1995 Cairo congress, a number of sessions discussed in a sharp and profound manner the technical matters related to the use of restorative justice approaches in the handling of criminal cases. The next congress in 2000, produced the United Nation, Basic Principles On The Use of Restorative Justice Programmes In Criminal Matters which contains a number of fundamental principles on the use of restorative justice approaches. ${ }^{3}$

"Restorative Justice" is a model approach that emerged in the era of the 1960s in an effort to solve criminal cases. Unlike the approach used in the conventional criminal justice system, this approach focuses on the direct participation of perpetrators, victims and society in the process of settlement of criminal cases. Apart from the fact that this approach is being debated in theory, but this view is in fact growing and it impacted the legal policies and practices in various countries.

At present, restorative justice approach is assumed as the most recent shift from the various models and mechanisms in the criminal justice system in handling criminal cases. UN through its basic principles that has been tailored, is of the opinion that restorative justice approach is an approach that can be used in the rational criminal justice system. This is in line with the view of G. P. Hoefnagels which states that Criminal Policy should be rational (a rational total of the responses to crime). ${ }^{4}$ The restorative justice approach is a paradigm that can be used to frame the criminal case management strategies aimed at answering the workings of discontent of the criminal justice system today.

Restorative justice is a concept that responds to the development of thought of the criminal justice system with emphasis on community involvement and the needs of victims to be felt, which is felt excluded by a mechanism that works in the criminal justice system that is being availed at the moment. On the other hand, restorative justice is also a new framework of thinking that can be used in response to a crime by the law enforcement. Following are some definitions of restorative justice:

\section{Dignan: ${ }^{5}$}

Restorative justice is a new framework for responding to wrongdoing and conflict that is rapidly gaining acceptance and support by educational, legal, social work, and counseling professionals and community groups.4 Restorative justice is a valued-based approach to responding to wrongdoing and conflict, with a balanced

\footnotetext{
${ }^{2}$ In many countries, this approach is adopted as a new frame work for their criminal justice system especially in juvenile cases in Philippines, New Zealand or Canada.

${ }^{3}$ UN Basic Principle On The Use of Restorative Justice Programmes in Criminal Matter, 2000. p.15-16

${ }^{4}$ Muladi and Barda Nawawi Arief, Teori-Teori dan Kebijakan Pidana, (Bandung, Alumni,1992) ${ }^{5}$ Ibid
} 
focus on the person harmed, the person causing the harm, and the affected community.

\section{Mark Umbreit: ${ }^{6}$}

Restorative justice provides a very different framework for understanding and responding to crime. Crime is understood as harm to individuals and communities, rather than simply a violation of abstract laws against the state. Those most directly affected by crime -- victims, community members and offenders -- are therefore encouraged to play an active role in the justice process. Rather than the current focus on offender punishment, restoration of the emotional and material losses resulting from crime is far more important.

\section{Braithwaite: ${ }^{7}$}

"On (the prosedural) view, restorative justice is a process that brings keadilantogether all stakeholder affected by some harm. That has been done... These stakehorlders meet in a circle to discuss how they have been affected by the harm and come to some agreement as to what should be done to right any wrongs suffered. ...Restorative justice is about healing (restorative) than hurting.

\section{Howard Zehr:8}

Viewed through a restorative justice lens, "crime is a violation of people and relationships. It creates obligations to make things right. Justice involves the victim, the offender, and the community in a search for solutions which promote repair, reconciliation, and reassurance."

\section{Burt Galaway and Joe Hudson: ${ }^{9}$}

A definition of restorative justice includes the following fundamental elements: "first, crime is viewed primarily as a conflict between individuals that results in injuries to victims, communities, and the offenders themselves; second, the aim of the criminal justice process should be to create peace in communities by reconciling the parties and repairing the injuries caused by the dispute; third, the criminal justice process should facilitate active participation by the victims, offenders, and their communities in order to find solutions to the conflict."

It is not easy to give a definition for this approach to restorative justice, considering the number of variations and models developed in the form of its application. Hence many of the terminologies are used to describe the flow of restorative justice, among others, "Communitarian justice (justice, communitarian), positive justice (fairness positive), relational justice (relational justice), reparative justice (justice reparative) and community justice (community justice) and the Communitarian justice". The terminology

${ }^{6}$ Mark Umbreit, "Avoiding the Marginalization and 'McDonaldization' of Victim-Offender mediation: A Case Study in Moving Toward the Mainstream" in Restorative Juvenile Justice Repairing the Harm of Youth Crime, edited by Gordon Bazemore and Lode Walgrave. Monsey, (NY: Criminal Justice Press. 1999). p.213

${ }^{7}$ John Braitwaite, Crime Shame and Reintegration,(Cambridge University Press,1990) p.xi

${ }^{8}$ Howard Zehr, Changing Lenses: A New Focus for Crime and Justice. Scottdale, Pennsylvania; Waterloo, Ontario: Herald Press, 1990.p 181.

${ }^{9}$ Burt Galaway and Joe Hudson, Criminal Justice, Restitution and Reconciliation. Monsey, NY: Criminal Justice Press., 1990. P. 2. 
used to refer to "Communitarian justice" comes from the communitarian theory developed in Europe today. ${ }^{10}$

Referring to such understanding, the handling of criminal cases through the restorative justice approach offers different views and approaches in terms of understanding and dealing with a crime. In terms of the meaning of restorative justice, criminal offense is essentially the same as the view of criminal law in general: an attack on individual and society and social relationships. ${ }^{11}$ However, in the restorative justice approach, the main victim of the occurrence of a crime is not a state, as it is in the current criminal justice system. ${ }^{12}$ Crime therefore creates an obligation to repair the damage to the relationship caused by a crime. ${ }^{13}$ Justice, in this approach, means a problem-solving search process in the criminal case. This process involves the offender, the victims, and the community as important actors in repairing, reconciling and guaranteeing the sustainability of the improvement efforts. ${ }^{14}$

\section{Application of Restorative justice in several countries}

A growing trend shows that restorative justice is only limited to certain crimes and is mostly applied in cases of crimes committed by children and teenagers in New Zealand, England and Wales, the Philippines and Canada. This view may be different if you look at the case in the post apartheid South Africa. ${ }^{15}$ The South African government instead applies the restorative justice approach to solve cases of violence committed by the Apartheid regime. ${ }^{16}$

The translation of restorative justice has resulted in a variety of formulations to accommodate a variety of values, philosophical views, terms, strategies, mechanisms, and even types of crimes and those who gets involved in them .. Some of the interesting part of these regulations are :

a. There are some countries like Australia, ${ }^{17}$ Canada, ${ }^{18}$ Finland, ${ }^{19}$ Ghana, ${ }^{20}$ Bulgaria, ${ }^{21}$ or Belgium, ${ }^{22}$ which translate the concept of mediation as an opportunity which opened a criminal case after the completion by the temporarily judicial system, or

\footnotetext{
${ }^{10}$ Ibid

${ }^{11}$ In fact, these changes can not be separated from the view of the science of criminology who saw the development in view crimes, crimes defining and the response that occurs over a criminal act. Although, it is not stated that the new criminology's view is similar to the view of restorative justice, but cannot be denied that the presence of both an impact on changing development paradigm as a result of this thinking. Koesriani Siswosoebroto, New Approach in Criminology, (Jakarta ; Publisher of University of Trisaksi), 2009.

12 Ibid

${ }^{13}$ Crime is a violation of people and relationships... It creates obligation to make things right. Ibid

${ }^{14}$ Ibid

${ }^{15}$ J. Llewelly and Robert Howse, Institution For Restorative Justice: The South African Truth And Reconciliation Commission, (Toronto: University of Toronto Law Journal, Summer, 1999), South African Law Commission, Sentencing Restorative Justice, (Pretoria: Closing date for Comments, 30 June 1997) being searched from http://wwwserver.law.wits.ac.za/sale/issue/ip7.html searched on 13th June, 2005.

${ }^{16} \mathrm{Ibid}$, post apartheid Government make a policy of State recovery through reconciliation between perpetrators and victims of the practice of restorative justice approaches.

${ }^{17}$ Crimes (Restorative Justice) Act 2004 Canberra, Australia

${ }^{18}$ Youth Criminal Justice Act -2002, Canada

${ }^{19}$ Act on Mediation in Criminal and Certain Civil Cases, Finland

${ }^{20}$ Children's Act, 1998. (Act 950). Ghana.

${ }^{21}$ Law on Mediation. Prom. SG. 110/17 Dec 2004. National Assembly of Bulgaria

${ }^{22}$ Law of 22 June 2005 on mediation. Government of Belgium
} 
b. There are some countries likely $\mathrm{UK},{ }^{23} \mathrm{New}$ Zealand, ${ }^{24}$ or South Africa, ${ }^{25}$ which included the concept as a part of the criminal prosecution system.

From these two concepts one can see that restorative justice, in view of the regulators, have been translated as a mechanism for handling criminal cases outside the criminal justice system as well as a philosophical criminal prosecution which gave birth to new forms of criminal sanctions for conventional types of crime.

The above description is offering just a few examples from the many countries who are trying to apply the restorative justice paradigm in the handling of criminal cases. It is interesting to see the development in the application of the restorative justice approach which is evident today. It appears the paradigm assumptions brought many positive changes which benefits both the community and the state. A number of these notable benefits are:

(a) That the society was given the opportunity to handle their legal problems in a manner which was felt to be more fair. In this case the principle of simple, clear and direct (or sederhana, terang and tunai) more widely known and used in the customary law in the handling of civil cases can also be applied in criminal law. Even more, the Indonesian customary law basically does not recognize differences in the legal proceedings of criminal or civil cases.

(b) Expenses of the State in some cases being reduced for example:

1) The burden of taking care of crimes which still can be solved independently by the community. Police officers, prosecutors and courts can focus on combating more dangerous crimes as narcotics, terrorism, human trafficking or gross human rights violations.

2) Administratively, the number of cases entering the justice system can be reduced so the burden of the institution of the courts are reduced.

(c) Budget expenses for the criminal justice system can see savings. In particular the penitentiary, where the focus of most of the criminal settlement ends with the imposition of imprisonment of perpetrators. ${ }^{26}$ It is expected that the birth of the new sanctions will be better and more efficient (as it is being developed in the draft of Penal Code which is currently used in Indonesia).

\section{Restorative Justice: Universal Values}

Many authors do not consider restorative justice to be a new concept. Its existence is probably as old as the criminal law itself. Even a thousand years before, the approach is cited as the main mechanism for the handling of crimes. Marc Levin stated that the traditional approach is now expressed as a progressive approach. ${ }^{27}$ Meanwhile, Hooker describes the universal elements of

${ }^{23}$ Youth Justice and Criminal Evidence Act, 1999, UK Parliament

${ }^{24}$ Corrections Act 2004. Parliament of New Zealand

${ }^{25}$ Probation Servcies Amendment Act, 2002. Republic of South Africa.

${ }^{26}$ From a number of studies conducted show that the problem was born of restraint system is likely the same in every country. A number of classical problems such as the capacity is not sufficient space (overcrowded), repetition of the crime problem (recidive) or labeling or stigmatization problems of a former convict. Making the penitentiary is not considered as an ideal institution to build a convict. From a study done by UNAFEI in 2000 in some countries in Asia actually proved this. UNAFEI, Institutional Treatment Profiles of Asia, (Tokyo: UNAFEI, 2000)

${ }^{27}$ Marc Levin, Restorative justice in Texas : Past, Present and Future, (Texas: Texas Public Policy 
the basis of customary law and the system as follows: ${ }^{28}$

(a) The distribution of obligation is often a function of an actual or putative Genealogical relationship;

(b) The community, defined on a whether Genealogical or a territorial basis, almost always has a greater right over land distribution than the individual occupier or possessor.

(c) The institution of please help and mutual help exemplify the individual's subjection to a common set of the obligations;

(d) ... all the customary law (adats posses the preservation of harmony between the community and nature).

The concept of customary law of Indonesia within the customary judicial institution has also got a concept which can be described as the roots of restorative justice. In Indonesia, the characteristics of customary law in every region/ province are generally very supportive in implementing a restorative justice. In connection with the violation or offense of indigenous customs, and its solving mechanisms, customary law has its own view. This includes actions that disturb the peace of life or violation of propriety in the society. The following are some examples of a breach of customary law: ${ }^{29}$

(a) An event action of the parties in the community;

(b) Actions that cause disturbance of balance;

(c) Disturbance of balance causes reaction;

(d) The reaction that arises serves to return from the disruption state to its original state.

This concept is very different from understanding a crime or offense in the sense of criminal law. Based on these definitions the properties of customary law can be stated as follows: ${ }^{30}$

\section{(a) Comprehensive and integrated}

Comprehensive and integrated nature is caused by the background of customary law, which is cosmic, in which one to another is being interrelated. As a result one can not be separated from the others. Likewise in the legal field, there is no separation between civil and criminal violations, violation of religion or morality, as well as its court trial.

(b) Open

Violations of customary provisions intend to maintain a sense of justice according to public awareness perception and be observant of the time, place, and circumstances ("village", "kala", and "patra" for people of Bali). As the society develops it will also influence the development of the settlement provisions in the customary law as these provisions are formulated on the basis of consensus.

Foundation,2005) Page 5-7 traced through www.TexasPolicy.com on 3 February, 2008

${ }^{28}$ I.Gede A.B.Wiranata, Indonesian Customary Law Its Development from period to another period, (Bandung: PT.Citra Aditya Bakti, 2005) page 60

${ }^{29}$ I.Gede A.B.Wiranata, Op Cit., Page 209-210

${ }^{30}$ Ibid, Page 207-209 


\section{(c) Distinguishing issues}

Customs violations do not see the problem solely from the actions and consequences, but also considers the background and who is being responsible. This view, will provide for a new type of settlement and legal action for a criminal act.

\section{(d) Justice at the request of}

The proceedings and examination of cases being in violation of customary law is based on the requests /or no request, and complaints from someone who was injured or treated unfairly.

\section{(e) Action of reaction or correction}

The legal officer acts upon the customary reaction; by taking steps to solve crimes not only against the perpetrators, but also impose correctional measures on family members or other actors, or to the relevant legal community, aiming to return the balance to its original state by organizing traditional ceremonies and so forth.

In the traditional view, there are no valid circumstances supporting the use of force to ensure adherence. An application of customary sanctions is an effort, to restore the space (location) to a state of no disturbance of public order. The customary sanctions is an effort to restore the disturbed balance. Therefore, in the past, activities of the judiciary including the criminal justice system could not be separated from religious activities, cultural and governmental activities, as well as the economy and other life. ${ }^{31}$

During the reign of the Majapahit ${ }^{32}$ and rule of Sultan Iskandar Muda ${ }^{33}$ the law book Kutara Manawa was written by Qonun Mangkuta Alam. The book is labeled as a criminal law book and holds reflections on the application of customary law. These reflections are still referenced in the application of customary law in some part of Indonesia In section X of the "Pandecten van het Adatrecht (1936)" it is explained that the customary sanctions can be: ${ }^{34}$

(a) Substitution of immaterial losses in various ways such as coercion to marry an insulted girl;

(b) Payments of "customary money" to the people affected, in the form of a sacred object instead of spiritual losses;

(c) Celebration (over the victim) to cleanse society of all the dirt supernaturally

(d) Closing of shame, apology;

(e) The various form of corporal punishment to death penalty

(f) Isolation of the community and putting people outside the legal system (in this case the restrictions by being isolated or to be sanctioned rights as members of indigenous peoples).

\footnotetext{
${ }^{31}$ Ibid Page 27

32 Slamet Mulyana, Nagarakretagama And Its historical interpretation, (Jakarta: Bhatara Karya Aksara, 1979)

${ }^{33}$ I Gede A.B. Wiranata, Op Cit, Page 5

${ }^{34}$ I Gede A.B. Wiranata, $O p$ Cit
} 
In this case, the main elements of restorative justice are willingness and participation of victims, perpetrators and society in the improvement of the criminal act which happens also to be a feature of customary law. In Kutara Manawa from Astacorah chapter 55-56, is noted a form of criminal prosecution for perpetrators of theft as follows: ${ }^{35}$

If a thief caught in the theft, subject to a death penalty, his wife and children, his property and the land was taken over by the king in power. If the thief has a male slave and a woman, he/she was not taken over by the king in power, but released from all debts to the concerned thief.

If the thief applies for life proposal, then he/she must give compensation for his release as many as eight strings, and pay a fine of four laksa to the king in power, pay damages to people affected by returning stolen properties as for twice.

In this case, Kutara Manawa has applied a statute where the interests of the victims come to be considered in a criminal prosecution decision, in the form of return loss.

In the Book of Simbur Cahaya and Kuntara Radjaniti or Cephalo 12 and 80 in Lampung, was mentioned for example that the settlement mechanism could be done through mediation: ${ }^{36}$

(a) Settlement between personal, family or the environment;

(b) Settlement with relatives chief mediator / chiefs;

(c) Settlement by the customary chief.

In other countries some prominent examples expressed by several authors of restorative justice comes from ancient laws among others: ${ }^{37}$

(a) The Book of Hammurabi (1700 BC) describes a compensation as one sanction for criminal acts against property;

(b) Book of Ur-Nammi Sumeria (2060 BC), states a compensation as one sanction for all types of criminal offenses

(c) Law of "Twelve Table" Roman (496 AD), regulates the payment of the amount as twice the price of goods for the perpetrators of theft cases.

The three examples above is just a small illustration of the criminal prosecution concept as it often was used in the past to describe the spirit of restorative justice.

\section{Prospects in Indonesia}

\section{Institution of Meeting Council}

In the Indonesian society the public consultation is regarded as part of the mechanism to solve a criminal case. Consultations are held by the perpetrators

\footnotetext{
${ }^{35}$ Slamet Mulyana, Ibid, Page 186

${ }^{36}$ I Gede A.B. Wiranata, Op Cit

${ }^{37}$ Ibid
} 
and the victims themselves or with the involvement of police or prosecutorial institution, or the traditional institutions in order to influence the public mindset to better detect an emerging problem. To include consultative problem solving in a crime case is the capturing of the underlying mindset of restorative justice, as defined above. Therefore, without ignoring the formal function of the legal system, the use of the institutional mechanism for consultative resolution is working in the community. In the various principles and models of restorative justice approaches, the process of dialogue between the perpetrator and the victim is fundamental and the most important part of the application of this justice. Direct dialogue between the perpetrator and the victim made the victim express what he felt, expressed his/her hope for human rights and desires of a criminal settlement. Through the dialogue process it also inspired the actors to correct themselves, realize mistakes and accept responsibility and $r$ the consequences of the criminal acts committed. From this dialogue process, the public can also participate in shaping the agreement and monitor its implementation.

By many authors studying restorative justice, this consultation institution is known as a highly institutionalized mediation in the civil justice system. The overall process which can be found restorative justice are as follows:

a. Victim Offender Mediation (VOM: Mediation between perpetrator and victim) is a process which encourages the establishment of a meeting between the perpetrator and the victim and includes a mediator as a coordinator and facilitator of the meeting. ${ }^{38}$

b. Conferencing is a process similar to VOM, however, in this form there are differences as it involves the settlement. This, does not only involve the perpetrator and the direct victim (primary victim), but also the indirect victims (secondary victim), such as family or friends close to the victim as well as family and close friends of the perpetrators. The reason for the involvement of the above parties is that they may be impacted either directly or indirectly in the committed crime. They may have a high concern and/or interest in the results of the consultation, and they can also participate in the making of a successful process and end result. ${ }^{39}$

c. A Circle is another model used in restorative justice. The application of this model is compared to the two previous mentioned models more involving in terms of stakeholders.. the stakeholders are not only the victim, perpetrator, family, or mediators, but also members of the public who are concerned with the case. ${ }^{40}$

These three basic models of application of restorative approaches are basically variations of the dialogue model which is as process of deliberation and consensus. The basic value of restorative justice is the same as the existing basic in Indonesian society which has got a strong foundation on values. however and unfortunately this model does not have any clear statutory justification.

${ }^{38}$ Daniel van Ness, Allison Morris dan Gabriel Maxwell, Introducting Restorative Justice dalam, Allison Morris dan Gabrielle Maxwell (editor), Restorative Justice for Juveniles: Conferencing, Mediation and Circles, (Oxford: Hart Publishing,2001) page 7
${ }^{39}$ Ibid
${ }^{40}$ Ibid 
Apart from thinking about the advantages and disadvantages of settling disputes outside the criminal system that is not formally recognized by the applicable law, restorative justice has become a necessity within the community. This is closely related to the principles and purposes of criminal prosecution of an indigenous justice system which is different from the existing formal system, resulting in a very different decision (in this case the author does not see what the impact is a positive or negative). However, in some of these situations, the existence of these institutions in a society still remains a choice to reach the final goal which can not be obtained through the criminal justice system, such as:

a. It provides a direct benefit which is recognized by, victims, perpetrators as well as the public .

A form of real compensation that manifests in the form of return of stolen goods, vehicle repairs to the provision of monetary compensation if the victims died.

b. Criminal settlement mechanisms with the restorative justice approach gives a wider role to the community.

In the criminal case settlement mechanisms with the restorative justice approach, the society's position is not only seen as an active participant or victim's participant. The society can, through this approach, be given a wider role in monitoring the implementation of the settlement agreement of criminal cases. Implementation can be done in various ways and could include monitoring the rehabilitation of victims. or monitoring the implementation of the perpetrator's accountability, which can be either restoration of damaged facilities, the return of goods, customs compliance, fines and so forth.

c. The process of handling the case through the restorative approach can be performed fast and precisely.

As it is not going through complicated bureaucratic procedures the settlement process of settlement, particularly for criminal cases resolved outside courts both within the criminal justice system or completed by the community by traditional institutions can be done fast.

This seems to be a simplified model of a settlement system for certain criminal cases. It is a well-known model for a criminal settlement through ordinary courts or judicial brief in Indonesian criminal legal procedure. Yet it seemed that the mechanism does not answer the needs of society as in the above exposure.

The evaluation of the criminal settlement with the existing principles of restorative justice is a measure in evaluating these cases. A lot of core values have been applied to make the restorative justice a pillar in the resolution of criminal cases. Some weaknesses remains in the understanding of the restorative approach justice. It is not yet complete in regard to the involvement of perpetrators and victims, the principle of pre innocent suspect, the achievement of equality in the settlement process. Weaknesses also remain in regard to the efforts to achieve the resolution which refers to the goal of restorative justice looking at the need for perpetrators, victims and communities to improve social relations between them. 
By looking for possibilities in applying restorative justice, the author noted that the Basic Principle For The Use Of Restorative Justice mandates this approach to be applied in the framework of a country`s legal system. This indicates that if this approach is to be used in Indonesia as part of the criminal settlement mechanism, then the criminal justice system must be adjusted so it can reach out and facilitate a criminal settlement mechanism through the restorative justice approach.

\section{Bibliography}

Fitriasih, Surastini et al, 2002., Access to Justice, (Jakarta: Sentra Ham-Komisi Hokum Nasional

Galaway, Burt and Joe Hudson, 1990, Criminal Justice, Restitution and Reconciliation. Monsey, NY: Criminal Justice Press.

Siswosoebroto, Koesriani., 2009, New Approach in Criminology, Jakarta: Penerbit Trisakti University

Levin, Marc., 2005, Restorative justice in Texas: Past, Present and Future, (Texas: Texas Public Policy Foundation, 2005) pp. Traced through www. TexasPolicy.com 5-7 on February 3, 2008

Llewellyn, Jennifer J. and Robert Hawse, 1999Institutions for Restorative Justice: The South African Truth And Reconciliation Commission, (Toronto: University of Toronto Law Journal, Summer)

Mulyana, Slamet., 1979, Nagarakretagama History and Interpretation, Jakarta: Aksara.

South African Law Commission, 1997, Sentencing restorative Justice, (Pretoria: Cloosing date for Comments, June 30) traced through http://wwwserver. law.wits.ac.za/salc/issue/ip7.html traced on June 13, 2005.

Umbreit, Mark., 1999, "Avoiding the Marginalization and 'McDonaldization' of Victim-Offender mediation: A Case Study in Moving Toward the Mainstream" in Restorative Juvenile Justice Repairing the Harm of Youth Crime, edited by Gordon Bazemore and Lode Walgrave. Monsey, NY: Criminal Justice Press.

Van Ness., Daniel Allison Morris and Gabriel Maxwell, 2001, Restorative Justice in Introducing, Allison Morris and Gabrielle Maxwell (editors), Restorative Justice for juveniles: Conferencing, Mediation and Circles, (Oxford: Hart Publishing)

Wiranata, I. Gede A.B. 2005, Customary Law of Indonesia Development from time to time, Bandung: PT.Citra Aditya Bakti.

Zehr, Howard., 1990, Changing Lenses: A New Focus for Crime and Justice. Scottdale, Pennsylvania; Waterloo, Ontario: Herald Press. 